\title{
A Study of China's Arbitration System Based on a Review of International FTA Arbitration Mechanisms
}

\author{
ZiHui Tang ${ }^{1, *}$ \\ ${ }^{1}$ School of Law, Ocean University of China, Qingdao, Shandong, China \\ ${ }^{*}$ Corresponding author. Email: 18150022057@stu.ouc.edu.cn
}

\begin{abstract}
Arbitration, as one of the most important means of international civil and commercial dispute resolution, has been widely used by the international community with the important feature of fully respecting the will of the parties. Due to the special economic and legal status of the FTZ, arbitration cases involving the FTZ cannot be fully equated with general arbitration cases, and the establishment and improvement of a set of diversified commercial dispute resolution mechanism in line with the actual FTZ is not only beneficial to the development and construction of the FTZ, but also conducive to the region's right to gain a voice in international commercial dispute resolution. Therefore, the improvement of the arbitration mechanism has become an important part of the system construction of the FTZ. Based on this, this paper further investigates the practical situation of the commercial arbitration system in China's FTZ based on a study of the current status of the commercial arbitration system and legislation in the FTZs of the United States and Singapore, and finally proposes problems and suggestions for improvement of the commercial arbitration system in China's FTZ. It aims to promote China to strengthen judicial assistance and arbitration supervision, improve the evaluation mechanism, and enhance the professionalism of the arbitration industry team in order to better serve international arbitration matters.
\end{abstract}

Keywords: Free Trade Zone, Arbitration, System, International Commercial

\section{INTRODUCTION}

Arbitration is a favored method of dispute resolution in modern commercial activities, which has the advantages of neutrality, flexibility, efficiency, enforceability, confidentiality and professionalism, and fully fits the characteristics of the current situation of disputes in the Pilot Free Trade Zone (FTZ). The construction of a pluralistic dispute resolution mechanism is an important part of the system construction of the FTZ, and therefore the establishment of an arbitration mechanism that fits the characteristics of the FTZ is of great significance in adapting to the development of the FTZ and the settlement of commercial disputes, attracting more international enterprises to settle disputes through the arbitration system, and improving the pluralistic dispute resolution mechanism. However, there are limitations to the direct application of China's existing commercial arbitration system to the FTZ [1]. On the one hand, the relevant provisions of China's Arbitration Law lag behind and are not compatible with the economic development level of the FTZ; on the other hand, the commercial disputes in the FTZ are special in nature and the commercial activities in the FTZ have their own special needs for the arbitration mechanism. Therefore, based on the complexity of commercial disputes and the diversity of dispute forms in the FTZ, this paper attempts to construct an arbitration mechanism specific to the FTZ and put forward ideas and suggestions to promote and safeguard the construction and development of the FTZ.

\section{AN EXAMINATION OF THE ARBITRATION MECHANISM IN FOREIGN TRADE ZONES}

\subsection{An Examination of the U.S. Foreign Trade Zone Arbitration Mechanism}

The U.S. arbitration system is one of the most mature arbitration systems in the world, and this section focuses on the ADR mechanism that has emerged in the U.S. to provide reference for the construction and development of China's FTZ arbitration system. ADR is a general term for alternative dispute resolution 
mechanisms outside of the civil litigation system, and is a form of alternative dispute resolution.

\subsubsection{Mediation and Arbitration System}

Mediation and arbitration means that a neutral third party acts as a mediator to help the parties resolve the dispute and reach an outcome that both parties are willing to accept; if the dispute is not successfully resolved, the arbitration process continues and the mediator's role is transformed into that of an arbitrator who makes the final decision. If the mediation fails, the parties do not need to find a neutral third party to whom they can restate the facts and reasons of the case, because the original mediator is already familiar with the facts of the case and can make an award directly in the arbitration process [2]. Of course, the procedure of uniting the mediator and the arbitrator also has certain drawbacks. For example, the provision that information disclosed by the parties in the mediation process cannot be used as evidence in the arbitration process can cause the parties to deliberately conceal relevant information in the mediation and affect the discovery and negotiation of evidence. Moreover, the impartiality of the arbitrator may be affected by his or her participation in the mediation, or at least create concerns among the parties that the arbitrator will not be able to remain neutral.

\subsubsection{Court-Associated Arbitration}

Court-annexed arbitration is a simplified informal hearing in which a judge-approved arbitrator makes an award after hearing the parties' arguments and reasons, and the award is final if the parties do not request a hearing in court within a certain period of time. The court-annexed arbitration system has three main functions: (1) Dispute resolution. Combining arbitration with justice assists the courts in resolving disputes. Parties to arbitration are able to agree in advance on the arbitration process, but cannot agree on the substantive rights relationship [3]. The court-annexed arbitration system can protect the arbitral award made by the arbitral tribunal from the substance. (2) The adjustment and repair function is mainly aimed at the repair of interpersonal relationships. At present, people are more and more aware of the rules, and after the acceptance of the rules, the parties to the dispute also value more the harmony and friendliness of interpersonal relations as well as the autonomy and reasonableness of the opportunity to resolve the dispute. (3) Supplementary helpful function. The court-annexed arbitration system is a bridge between arbitration and litigation. Compared with litigation procedures, the procedural benefits of court-annexed arbitration system mainly include:low cost, rapid and convenient:convenient and flexible procedures, high participation of the parties; can solve multifaceted and multi-level disputes and interest claims at one time:strong confidentiality, reducing the damage to the relationship between the parties.

\subsection{An Examination of Singapore's Freeport Arbitration Mechanism}

\subsubsection{Status of Legislation of Commercial Arbitration System in Singapore}

Unlike China, Singapore's FTZ adopts a "legislation first, zone later" model. The Singapore International Arbitration Act has been amended five times since its enactment, and the latest version contains seven new provisions, including: (1) Broadening the scope of arbitration agreements to include arbitration agreements entered into by the parties, whether orally, by conduct or otherwise, to include written arbitration agreements. (2) Allowing judicial review of a court's decision to deny jurisdiction. (3) Broaden the power of an arbitral tribunal to award interest on the payment of money. (4) If the court's judicial review of the tribunal's self-denial of jurisdiction results in a lack of jurisdiction, then the court may order the parties to pay the costs of the proceedings as well as the costs of the necessary arbitration proceedings. (5) Decisions and orders made by the emergency arbitrator shall be valid. (6) Interim orders of emergency arbitrators and interim awards are enforceable. (7) To clarify the applicable law on the statute of limitations for arbitration of cross-border disputes.

\subsubsection{Review of the Arbitration Agreement, Arbitral Tribunal and Arbitral Award System in Singapore}

(1) An arbitration agreement is a written agreement between the parties to submit a dispute that has arisen or may arise to an arbitral institution for settlement, and the arbitral institution or tribunal acquires jurisdiction under the arbitration agreement and excludes the jurisdiction of the courts [4]. Of course, if the arbitration agreement is invalid, such as if the parties have violated the mandatory provisions of the law, exceeded the limits of law and morality, or harmed the interests of third parties or the public interest, the arbitral award rendered may be refused recognition and enforcement under the New York Convention and the UN Model Law on International Commercial Arbitration.

(2) The arbitral tribunal, by virtue of the powers conferred by the arbitration agreement, applies the principle of discretionary jurisdiction in respect of its own jurisdiction. a: The principle of discretionary jurisdiction of the arbitral tribunal: The arbitration agreement or arbitration clause is independent of the contract or other provisions of the contract. Arbitrators, whether domestic or international, have the power to determine their own jurisdiction. The principle of 
discretionary jurisdiction gives the arbitral tribunal the power to proceed in the event of a challenge to the existence or validity of the arbitration agreement. b: Emergency Arbitrator Mechanism: An emergency arbitrator is an arbitrator appointed by the parties or by the Arbitration Commission, who has the power to make an order for interim relief, an award for interim relief or an award to meet the parties' needs for preservation of property, evidence or other relief, and once made, is effective against the parties. Once made, the award is effective against the parties [5]. The award shall be enforceable in Singapore and the emergency arbitrator shall automatically lose all powers once the tribunal has been constituted and shall not continue to act as arbitrator in any proceedings unless otherwise agreed by the parties.

(3) With respect to the enforcement of an arbitral award, once an arbitral award has been made, it means that the parties are automatically obliged to perform that award. This is an implied term in all arbitration agreements. If an award is made, but the parties do not voluntarily perform it, it becomes a "blank check". The New York Convention was enacted to provide a legal basis for the recognition and enforcement of arbitral awards in its member states. The New York Convention does not set a uniform standard for enforcement, but rather sets minimum standards that national courts must follow to facilitate the recognition and enforcement of foreign arbitral awards.

\section{STUDY OF ARBITRATION MECHANISM IN CHINA'S FREE TRADE ZONE}

\subsection{Examination of Arbitration Mechanism in Shanghai Pilot Free Trade Zone}

At present, there are no special laws and administrative regulations for the FTZ in China, and only a small amount of contents in the Foreign Trade Law and Customs Law are related to the FTZ. At the beginning of the establishment of Shanghai Pilot Free Trade Zone, a series of normative documents" for the construction of the Pilot Free Trade Zone were issued, which comprehensively regulate the construction of the Pilot Free Trade Zone in nine aspects: management system, investment opening, trade facilitation, financial services, taxation management, comprehensive supervision, and rule of law environment. The State Council departments as well as the Shanghai Municipal Government and its General Office have issued a series of documents related to the FTZ. As the system innovation and reform experiments in the Shanghai FTZ continue to advance, the rule system of the FTZ is also being improved. The Shanghai Pilot Free Trade Zone International Arbitration Center has formulated the Shanghai Pilot Free Trade Zone Arbitration Rules, which fully draws on the internationally prevailing arbitration rules and introduces many advanced arbitration systems, providing an important reference and direction for all other FTZ arbitration institutions.

\subsection{Examination of the Arbitration Mechanism in Guangdong Pilot Free Trade Zone}

The Guangdong Pilot Free Trade Zone is the second batch of FTZs in China, and its arbitration institution is the integrated Shenzhen International Arbitration Institute (SIAI), which has adopted a management model centered on a board of directors to achieve the independence of the arbitration institution and the arbitral tribunal, changing the status quo of Chinese arbitration institutions, which have always been administrative in nature with the government as the background. The Opinions on Judicial Protection issued by the Supreme People's Court provide for the "limited introduction" of ad hoc arbitration, which is seen as a "unbundling" of the ad hoc arbitration system. However, as the arbitration legislation in mainland China does not yet recognize ad hoc arbitration, parties who wish to resolve their disputes through ad hoc arbitration can only seek relief from overseas or extra-territorial arbitration rules, which makes it impossible to effectively "land" the introduction of ad hoc arbitration under the current legal framework [6]. The Zhuhai Arbitration Commission formulated the Hengqin Pilot Free Trade Zone Interim Arbitration Rules (hereinafter referred to as the Interim Arbitration Rules) in accordance with the Supreme Court's Judicial Protection Opinions, filling the gap of no interim arbitration rules in China.

\subsection{Examination of the Arbitration Mechanism in the Hainan Pilot Free Trade Zone}

The Hainan Pilot Free Trade Zone (FTZ) is China's newest pilot free trade zone (port). Hainan Arbitration Commission (now renamed Hainan International Arbitration Court) in 2000 completely no longer rely on financial support, self-supporting. The value of cases handled by the HAC exceeded 10 billion yuan in 2016 . In terms of international cooperation, HAIAC has signed arbitration cooperation agreements with arbitration institutions in Southeast Asian countries, and has stationed arbitration offices in other countries. In the context of the construction of Hainan Pilot Free Trade Zone (FTZ), we should make full use of the preferential policies of the FTZ construction, maximize the advantages of arbitration experts and institutions, promote the process of building an international arbitration institution, and provide a strong rule of law guarantee for creating a first-class business environment in Hainan FTZ. 


\section{PROBLEMS OF CHINA'S FTA ARBITRATION MECHANISM AND SUGGESTIONS FOR SOLUTIONS}

\subsection{Main Problems}

\subsubsection{Uneven Coverage of Specialized Arbitration Institutions}

At present, Chongqing, Hubei Liaoning and a few other FTA pilot zones have not yet set up specialized arbitration institutions, and there is also the phenomenon of uneven setting of FTA arbitration institutions within the same provincial (city) FTA zone. For example, only the Zhengzhou Pilot Free Trade Zone in Henan has set up an international commercial arbitration court, while the Luoyang and Kaifeng zones have not. As the number of enterprises in the FTZ is rapidly increasing and the speed of commercial disputes is expected to rise, it is important to ensure that professional arbitration institutions are located and operating in as many FTZs as possible in order to facilitate the quick resolution of disputes and mitigate the commercial impact on enterprises and investors in the FTZ.

\subsubsection{Imperfect laws and regulations on arbitration in FTZs}

(a): Lack of legislation at the national level: Unlike the United States and Singapore, which adopt the model of "legislation first, zone later", China has not yet enacted a law applicable to the whole China Pilot Free Trade Zone, i.e., a higher level of law is missing. Scholars are also divided on the question of whether China should enact a "China FTZ Law". In addition, China's current Arbitration Law does not yet recognize international arbitration systems such as ad hoc arbitration system and emergency arbitrator system, making it impossible for the relevant arbitration rules developed by various arbitration institutions to be implemented in China [7]. Therefore, this paper argues that the FTA arbitration system should be recognized in the national legislation as soon as possible.

(b): Weak operability and unclear legal characterization of the General Scheme: At the beginning of each FTZ, the State Council issued the General Scheme of the FTZ (hereinafter referred to as the "General Scheme") as the most important regulatory document for the construction of each FTZ. The contents covered in the General Plan are related to financial reform, tax regulation, transformation of government functions, rule of law construction, etc., but most of the contents are at the level of formality and weak operability. In addition, because the General Plan was jointly formulated by the Ministry of Commerce and local governments and promulgated by the State Council after approval, there is a problem of inconsistency between the subject of formulation and the subject of approval, so the legal status of the General Plan is still controversial and will be limited in its application.

(c): local legislation is too complicated: under the premise of the General Plan as the basic basis for the construction of the Pilot Free Trade Zone, the respective pilot trade zones have issued some normative documents one after another. (hereinafter referred to as "Management Measures for Pilot Free Trade Zones") issued by local governments to deal with the daily management of the zones, and "Regulations for Pilot Free Trade Zones" (hereinafter referred to as "Regulations") formulated by local people's congresses, which have made specific provisions for the construction of pilot free trade zones. On the whole, most of the legal norms of the FTZs around China are local legislation, with low legal rank and prone to conflicts with higher laws. The management authority of FTZs is mostly in the hands of local governments, while the functions of management committees as FTZ management agencies are restricted, which is not conducive to their active participation in FTZ management and affects the efficiency of their work.

\subsubsection{Low Supply of Arbitration Rules and Judicial Review Rules in FTZs}

The Shanghai Pilot Free Trade Zone (FTZ), the earliest established FTZ, is the most well established in terms of the construction of the arbitration system. It has issued the "FTZ Arbitration Rules

Zone Arbitration Rules, and the Shanghai Second Intermediate Court has also provided special judicial review opinions for it. Tianjin and Liaoning FTZs have also issued special arbitration rules, and Hengqin FTZ in Guangdong has issued China's first interim arbitration rules, but none of them yet has special rules for judicial review. The judicial review in Tianjin and Guangdong is carried out by reference to the "Guidelines for the Hearing of Commercial Arbitration Cases Involving Foreign Countries, Hong Kong, Macao and Taiwan". Other FTAs have not yet developed specific arbitration rules and judicial review rules. The current situation of imperfect laws and regulations and the lack of arbitration rules and judicial review rules is not conducive to the efficient, flexible and convenient resolution of commercial disputes in the zone. In view of the above, this paper suggests that relevant laws and regulations and their accompanying arbitration rules should be introduced to provide theoretical support for the construction of arbitration mechanism in FTZs. 


\subsection{Solution suggestions}

\subsubsection{Introduction of arbitration agreement}

(a) Expand the scope of arbitration agreement admissibility. In China's arbitration system, some regional arbitration rules have already expanded the scope of the form of arbitration agreements beyond the written form. The need for improvement lies in further clarifying what is "in writing" and when it is "deemed to be in writing".

(b) Relaxing the requirement of the substantive elements of the arbitration agreement, i.e., not directly invalidating an agreement to arbitrate or adjudicate. If the parties agree that they have the option of both arbitration and court litigation in the event of a dispute, this means that the parties have the will to arbitrate and therefore cannot directly invalidate the parties' arbitration agreement. The recommendation of this article is that if the parties have agreed to both arbitration and litigation, the method of dispute resolution chosen by the party who first initiated the dispute resolution may take precedence.

(c) In the event that the parties agree on an arbitration institution where the agreement is unclear, the choice is not directly found to be invalid. The current number of arbitration institutions in China is so large that this practice has not kept pace with the current development of the Chinese economy and should be amended so that the appropriate arbitration institution can be inferred from the content of the parties' dispute and the nature of the contract.

\subsubsection{Clarify the self-adjudication jurisdiction of the arbitral tribunal}

In China, the court has priority in ruling on the jurisdiction of the arbitral tribunal. Although the parties can request a ruling on the arbitration agreement from both the arbitration committee and the court, if each party seeks a side, the court will have priority. This article argues that China should expeditiously delegate the exercise of jurisdictional decisions to the arbitral tribunal in the form of legislation. This is not conducive to ensuring the efficiency of arbitration and is one of the reasons for the waste of judicial resources. As for the emergency arbitrator system, it is currently enforced in some countries, while some countries do not recognize or enforce it, which is still controversial internationally. Therefore, the actual situation and operation of the emergency arbitrator system in China can be observed again at home and abroad.

\section{CONCLUSION}

As a window and an important part of China's new reform and opening-up strategy, the FTZ demonstrates to the world both the traditional Chinese spirit of friendship, tolerance and fraternity, and is also significant for China's future economic development and maintenance of its international status. Along with the in-depth promotion of the FTZ strategy, international commercial disputes are not only increasing in number and type, but also in difficulty of dispute resolution. Therefore, the establishment and improvement of advanced dispute resolution mechanism in the FTZ is crucial to the long-term and healthy development of the FTZ. The arbitration system in China's FTZs is an important part of the rule of law construction in China's FTZs and has a positive impact on the construction and development of FTZs. However, China's general commercial arbitration system can hardly meet the requirements of internationalization, specialization and facilitation of the arbitration system in the FTZ due to its own limitations, so it is necessary to build an arbitration system serving the FTZ.

\section{REFERENCES}

[1] Xu ZZ, Tang SJ. Suggestions for Improving the Interim Arbitration System in the Free Trade Zone from a Legal Perspective[J]. Law Review, 2021 (27):44-45.

[2] Wang R. Research on the legal path of innovation and regulation in China's free trade zone [J]. Modern Marketing (Academy Edition),2021 (08):186-187.

[3] Xu ZZ. The value and significance of commercial arbitration law to the construction of China's free trade zone[J]. Law and Society,2021(21):117-119.

[4] Xu HZ, Nian FF. The dilemma and the way out of the construction of temporary arbitration system in Liaoning Free Trade Zone[J]. Law and Society, 2021(21):120-121.

[5] Gou AB. A Preliminary Study on the Elements of Interim Arbitration Agreement under the Perspective of Arbitration Innovation in Free Trade Zone[J]. China Justice, 2020(11):40-45.

[6] Chen YN. On the dilemma of ad hoc arbitration in China's free trade zone and countermeasures[J]. Journal of Heilongjiang Academy of Political and Legal Management Cadres,2020(04):115-118.

[7] Zhang SC, Fu ZJ. Research on the innovation of temporary arbitration system in China's free trade zone [J]. Journal of Shanghai University of Finance and Economics,2019,21(02):140-152. 